\title{
Role of Single Dose Intramuscular Betamethazone in Reducing Hospitalization Rates in Acute Asthma
}

\author{
Jayasree $\mathbf{P}^{1}$ \\ ${ }^{1}$ Professor, Department of Paediatrics, Mount Zion Medical College, Adoor, Kerala.
}

\section{Abstract}

Background: Children with asthma are predisposed to exacerbations. This holds irrespective of the type of asthma the reason for exacerbation can be a viral illness, physical activity or exposure to allergens. Hospitalization of patients with acute attack poses financial and other problems. Subjects and Methods: The participants of the study were children aged 1-12 years with acute attack of asthma coming to OPD/casualty of department of Paediatrics, Mount Zion medical College, Adoor. Results: Among 74 responders, there were 32 patients had mild type asthma (mild persistent and intermittent) (43.2\%), 32 had moderate (moderate persistent) type asthma (43.2\%) and 10 had severe (severe persistent) type asthma. The corresponding groups among non- responders were mild-8 (30.8\%), moderate 11 (42.3\%) and sever e 7 (26.9\%). Though it seems that percentage of severe asthma is more among non- responders, (26.9 \% v/s 13.6\%), the two groups are comparable when analysed statistically (standard error of difference between proportions was 9.5 and observed difference 13.3). the other groups were also comparable. Thus the type of asthma did not affect the response. Conclusion: Thus this study emphasizes the role of single dose IM betamethasone in preventing hospitalization rate in patients with moderate attack of asthma if used early.

Keywords: Intramuscular Betamethasone, Hospitalization Rates, Acute Asthma.

Corresponding Author: Dr. Jayasree P, Professor, Department of Paediatrics, Mount Zion Medical College, Adoor, Kerala.

Received: February 2019

Accepted: February 2019

\section{Introduction}

Asthma is a major cause of chronic respiratory problem in childhood. It is one of the most frequent admitting diagnosis in children's hospitals and is an important cause for school days lost. Asthma prevalence seems to be increasing world wide. ${ }^{[1]}$ WHO estimates that there are approximately 100 million asthmatics world wide. Deaths due to asthma, though rare in childhood, have increased over the past decades. ${ }^{[2]}$

Children with asthma are predisposed to exacerbations. This holds irrespective of the type of asthma the reason for exacerbation can be a viral illness, physical activity or exposure to allergens. Hospitalization of patients with acute attack poses financial and other problems. In the management of acute attack, inhaled salbutamol and systemic steroids are of proven benefit. ${ }^{[3]}$ Early use of steroids in preventing worsening of asthma has been studied. ${ }^{[4]}$ There are studies on the efficacy of methyl prednisolone and oral prednisolone. ${ }^{[5,6]}$ Methyl prednisolone is expensive and oral prednisolone may not be tolerated by children. In this study single dose betamethasone is given as steroid. It is longer acting and more potent than dexamethasone. ${ }^{[7]}$ The adverse effects following single dose is few and mineralocorticoid activity is practically nil8.it si also cheaper compared to methylprednisolone.

The study uses only one dose of betamethasone and also attempts to study the control of symptoms in the succeeding week.

Aims:

1. To study the efficacy of single dose intramuscular betamethazone in reducing the severity and hospitalization rates in acute asthma in children

2. To compare the effect of single dose intramuscular betamethazone in mild and moderate attacks of bronchial asthma

\section{Subjects and Methods}

\section{Subjects and methods:}

The participants of the study were children aged 1-12 years with acute attack of asthma coming to OPD/casualty of dept of Paediatrics, Mount Zion medical College, Adoor

\section{Study period:}

1 year- from August 2017 to August 2018

Study design:

Descriptive study Selection of patients

\section{Inclusion criteria:}

Patients aged 1-12 years presenting with acute attack of bronchial asthma of mild and moderate intensity (classified according to standard definition) 


\section{Jayasree; Single Dase Intramuscular Betamethazane}

\section{Exclusion criteria:}

- Children with first attack of wheezing

- Patients on controller medications

- Patients whose present attack is more than 24 hrs duration

- Those who have received any kind of treatment from outside

- Patients with history of clinical findings suggestive of associated bacterial infection

- Patients with other illnesses like tuberculosis

- Patients lost for follow up
Intervention: Inj Betamethazone sodium phosphate injection

Dose: $0.2 \mathrm{mg} / \mathrm{kg} \mathrm{IM}$

Intervention and outcome measures

There were 100 children who satisfied inclusion and exclusion criteria. Detailed history was taken and their asthma status was classified into mild, moderate and severe groups according to standard definition. ${ }^{[10]}$

\begin{tabular}{|l|l|l|l|l|}
\hline Components & Intermittent & Mild persistent & Moderate persistent & Severe persistent \\
\hline Day time symptoms & $</=2$ days/week & $\begin{array}{l}>/=2 \text { days/week but not } \\
\text { daily }\end{array}$ & Daily & Throughout day \\
\hline Night time awakenings & 0 & $1-2 /$ month & $3-4 /$ month & $>1 /$ week \\
\hline Short acting beta agonist use & $</=2$ days/week & $\begin{array}{l}>/=2 \text { days/week but not } \\
\text { daily }\end{array}$ & Daily & Several times/day \\
\hline $\begin{array}{l}\text { Interference with normal } \\
\text { activity }\end{array}$ & None & Some limitation & Extremely limted \\
\hline
\end{tabular}

The present asthma attack was also classified as mild moderate or severe according to standard guidelines 11.5 out of 9 criteria was taken to classify patients.

Classification of present asthma attack

\begin{tabular}{|l|l|l|l|}
\hline Parameter & Mild & Moderate & $\begin{array}{l}\text { Severe/life } \\
\text { threatening }\end{array}$ \\
\hline Resp rate & Normal & increased & greatly increased \\
\hline Alertness & Normal & restless & Restless/obtunded \\
\hline Speech & $\begin{array}{l}\text { speaks in } \\
\text { complete } \\
\text { sentences }\end{array}$ & $\begin{array}{l}\text { speaks } \\
\text { phrases or } \\
\text { partial } \\
\text { sentences }\end{array}$ & $\begin{array}{l}\text { Severe, speaks words } \\
\text { or unable to speak }\end{array}$ \\
\hline $\begin{array}{l}\text { Accessory } \\
\text { muscle use }\end{array}$ & Absent & Mild & $\begin{array}{l}\text { Moderate/paradoxical } \\
\text { chest movements }\end{array}$ \\
\hline Color & Normal & Pale & Cyanosed and \\
\hline Auscultation & $\begin{array}{l}\text { End } \\
\text { expiratory } \\
\text { wheeze }\end{array}$ & $\begin{array}{l}\text { Entire } \\
\text { expiratory }\end{array}$ & $\begin{array}{l}\text { Inspiratory } \\
\text { expiratory } \\
\text { Breath } \\
\text { inaudible }\end{array}$ \\
\hline Heart rate & Normal & Increased & $\begin{array}{l}\text { Greatly } \\
\text { increased/falling }\end{array}$ \\
\hline Sp O2 & $>95 \%$ & $92-95 \%$ & $<92 \%$ \\
\hline Pa CO2 & $<38$ & $38-42$ & $>42$ \\
\hline PEFR & $>80 \%$ & $60-80 \%$ & $<60 \%$ \\
\hline
\end{tabular}

Those with severe attack were not included in the study. In the group with mild and moderate attack, patients were randomized and almost one third patients received nebulized salbutamol alone and two thirds, nebulized salbutamol with Inj betamethazone.

In patients with moderate attack also, same intervention was applied.

All patients were reassessed after $30 \mathrm{~min}$ and response was divided into good, intermediate and poor response. If response was good, reassessment was done at 1 hour, 6 hours and 10 hours. 2 more nebulizations were given if required, for patients whose response shifts down to intermediate in between. Patients showing 'intermediate response' even after repeat nebulizations and patients showing 'poor response' were taken as failure of intervention.

All patients who were discharged were asked to continue oral salbutamol $0.1 \mathrm{mg} / \mathrm{kg} /$ dose 8 hourly for next 5 days. They were asked to come for follow up after 5 days. If patients became symptomatic in between or required additional steroids, they were considered as 'failure'.

Statistics: Fishers Exact test

\section{Results}

There were total 100 patients enrolled in the study. 63 received Inj betamethazone and the rest did not receive. 74 patients responded which included 54 from the betamethazone group and 20 from the other group. Some responders remained symptomatic in the succeeding week. Non responders included those who failed during observation and those who became symptomatic in the succeeding week. Various parameters were analyzed among those who responded and those who did not.

Age: out of 100 patients, 19 belonged to 1-3 years, 56 belonged to 3-6 years and rest 25 belonged to 6-12 years age group.

Among the responders, the split up was 14, 41 and 19 respectively, making total of 74 children. The mean age calculated was 4.76 and standard deviation 2.19.

Among the non responders, 5 were in 1-3 years age group, 15 in 3-6 years age group and 6 in 6-12 years age group making total of 26 children. The mean age was 4.67 with standard deviation of 2.37 .

Table 1: Age Distribution.

\begin{tabular}{|l|l|l|}
\hline Age & Responders & Non responders \\
\hline Mean & 4.76 & 4.67 \\
\hline SD & 2.19 & 2.37 \\
\hline
\end{tabular}

The difference between the 2 groups was not statistically significant. (SE of difference between 2 means was 0.52) 


\section{$\underline{\text { Sex }}$}

There was slight male preponderance with 52 boys and 48 girls making a sex ratio of 1.08:1. Among 52 boys, 38 belonged to responders (51.35\% of patients in this group) and 14 belonged to non responders $(53.8 \%$ of patients in this group)

The male to female ratio among responders was $38: 36$, ie 1.05:1 and among non-responders it was 14:12, ie 1.17:1. The difference in sex ratio between 2 groups was not statistically significant. (SE of difference was 11.37 with observed difference of 2.45)

\section{Geography}

44 patients were from rural areas and 56 from urban areas.

Among 74 responders, 33 were from rural areas and 41 from urban areas (44.6\% and 55.4\%)

Among 26 non responders, 11 were from rural areas and 15 from urban areas (42.3\% and $57.7 \%)$.

\section{Table 2: Locality.}

\begin{tabular}{|l|l|l|}
\hline Type of residence & Responders & Non responders \\
\hline Rural & $33(44.6 \%)$ & $11(42.3 \%)$ \\
\hline Urban & $41(55.4 \%)$ & $15(57.7 \%)$ \\
\hline
\end{tabular}

The difference between the two groups was not statistically significant (SE was 11.28 with observed difference of 2.3)

\section{Pollution}

A history of pollution/passive smoking was obtained in all patients. In 86 patients, there was a positive history. 66 were among responders (ie $89.2 \%$ of patients who responded had history of environmental pollution) 20 were among non responders ( $76.9 \%$ of all non responders)

\begin{tabular}{|l|l|l|}
\hline Table 3: Source of Pollution \\
\hline Source of pollution & Responders & Non responders \\
\hline Indoor & 52 & 14 \\
\hline outdoor & 11 & 4 \\
\hline both & 3 & 2 \\
\hline
\end{tabular}

The difference in pollution between these 2 groups was not statistically significant. (SE of 9.01 with observed difference of 12.3)

Among those with positive history, 66 had exposure to passive smoking, 15 had outdoor air pollution (house on roadside, nearby factory etc) and 5 had both.

\section{Family history}

71 patients had positive family history of asthma. Among the responders, 53 had positive family history. (71.6\%) and among non- responders, 18 had positive family history $(69.2 \%)$.

\section{Table 4: Family history}

\begin{tabular}{|l|l|l|}
\hline Family history & Responders & Non-responders \\
\hline$+\mathrm{ve}$ & $53(71.6 \%)$ & $18(69.2 \%)$ \\
\hline$-\mathrm{ve}$ & $21(28.4 \%)$ & $8(30.8 \%)$ \\
\hline
\end{tabular}

The difference between the 2 was not statistically significant (SE of 10.46 with observed difference of 2.4)

Type of asthma (with respect to chronicity)

Among 74 responders, there were 32 patients had mild type asthma (mild persistent and intermittent) (43.2\%), 32 had moderate (moderate persistent) type asthma $(43.2 \%)$ and 10 had severe (severe persistent) type asthma. The corresponding groups among non- responders were mild-8 $(30.8 \%)$, moderate $11(42.3 \%)$ and sever e 7 (26.9\%). Though it seems that percentage of severe asthma is more among non- responders, $(26.9 \% \mathrm{v} / \mathrm{s} 13.6 \%)$, the two groups are comparable when analyzed statistically (standard error of difference between proportions was 9.5 and observed difference 13.3). the other groups were also comparable. Thus the type of asthma did not affect the response.

Table 5: Asthma
\begin{tabular}{|l|l|l|}
\hline Asthma & Responders & Non-responders \\
\hline Mild & $32(43.2 \%)$ & $8(30.8 \%)$ \\
\hline Moderate & $32(43.2 \%)$ & $11(42.3 \%)$ \\
\hline severe & $10(13.6 \%)$ & $7(26.9 \%)$ \\
\hline
\end{tabular}

\section{Treatment factor}

Among 100 patients in the study, 63 received Inj betamethasone and 37 did not receive. Among the 63 patients who received the injection, 54 responded and among 37 who did not receive betamethasone, 20 responded. This difference was statistically significant $(\mathrm{p}<0.001)$. thus, with all the above parameters remaining same, the response depended on the administration of Inj betamethasone.

\section{Table 6: Treatment}

\begin{tabular}{|l|l|l|}
\hline Study group & Responders & Non-responders \\
\hline $\begin{array}{l}\text { Betamethasone group } \\
(\mathrm{n}=63)\end{array}$ & 54 & 9 \\
\hline $\begin{array}{l}\text { Non betamethasone } \\
\text { group (n=37) }\end{array}$ & 20 & 17 \\
\hline P<0.001 Fihex & & \\
\hline
\end{tabular}

$\mathrm{P}<0.001$ Fishers exact test

From the study, several other observations were made. 56 patients had mild attack at start and 44 had moderate attack. Among the 56 with mild attack, 30 received betamethasone, of which 25 responded. 26 did not receive betamethasone, of which 19 registered as a 'pass'. This was not statistically significant $(\mathrm{p}=0.544)$

\begin{tabular}{|l|l|l|}
\hline Table 7: Treatment of patients with moderate attack \\
\hline Study group group & Responders & Non-responders \\
\hline $\begin{array}{l}\text { Betamethasone grous } \\
(\mathrm{n}=30)\end{array}$ & 5 \\
\hline $\begin{array}{l}\text { Non betamethasone } \\
\text { group (n=26) }\end{array}$ & 19 & 7 \\
\hline
\end{tabular}

$\mathrm{P}=0.544$ by Fishers exact test

Among 44 patients with moderate attack, 33 received betamethasone, of which 29 responded. 11 did not receive betamethasone, and $10 \mathrm{f}$ these 'filed'. This was statistically 


\section{Jayasree; Single Dase Intramuscular Betamethazane}

significant $(\mathrm{p}=0.0004)$

\section{Duration of attack at presentation}

Among 74 responders, the mean duration of attack at presentation was $5.91 \mathrm{hrs}$ (range 1-17 hrs) with a SD of 4.32, whereas among the non-responders it was $8.5 \mathrm{hrs}$ (range 3-17 hrs) with a SD of 3.38. this difference was statistically significant and so was important in deciding the response. In the non-responder group, there was a child whose duration of attack was only $3 \mathrm{hrs}$ at presentation, but there was a history of brittle asthma in that patient which has probably contributed to the lack of response. Also betamethasone was not given to this child.

\begin{tabular}{|c|c|c|}
\hline \multicolumn{3}{|c|}{ Table 8: Duration of attack before treatment } \\
\hline & Mean (hours) & SD \\
\hline Responders $(\mathrm{n}=74)$ & $5.91(1-17)$ & 4.32 \\
\hline Non-responders $(\mathrm{n}=26)$ & $8.5(3-17)$ & 3.38 \\
\hline
\end{tabular}

Among the betamethasone group, 54 responded and 9 did not repond. The mean duration of attack at presentation was $5.67 \mathrm{hrs}$ (range 1-17) with SD of 2.62 among responders and
$10.67 \mathrm{hrs}$ (5-17) with a SD of 3.86 among non-responders. The difference was statistically significant.

Among the non- betamethasone group $(n=37) 20$ responded and 17 did not. The mean duration of attack among responders was 5.75 hours with a SD of 2.64 (range 1-12 hours) and among responders it was 7.35 hours (range 3-12 hours) with SD of 2.42. The difference was not statistically significant.

Table 9: Duration of attack among Betamethasone group

\begin{tabular}{|l|l|l|}
\hline $\begin{array}{l}\text { Betamethasone group } \\
(\mathbf{n}=\mathbf{6 3})\end{array}$ & Mean (hours) & SD \\
\hline Responders $(\mathrm{n}=54)$ & $5.67(1-17$ hours $)$ & 2.62 \\
\hline Non responders $(\mathrm{n}=9)$ & $10.67(5-17$ hours $)$ & 3.86 \\
\hline
\end{tabular}

Table 10: Duration of attack among Non betamethasone group.

\begin{tabular}{|l|l|l|}
\hline $\begin{array}{l}\text { Non betamethasone } \\
\text { group }(\mathbf{n}=\mathbf{3 7})\end{array}$ & Mean (hours) & SD \\
\hline Responders $(\mathrm{n}=20)$ & $5.75(1-12$ hours) & 2.64 \\
\hline Non responders $(\mathrm{n}=17)$ & $7.35(3-12$ hours) & 2.42 \\
\hline
\end{tabular}

\begin{tabular}{l}
\hline Table 11: Failures in Betamethasone group $(\mathbf{n}=\mathbf{6 3})$ \\
\begin{tabular}{|l|l|l|l|l|l|}
\hline \multirow{3}{*}{ Failure $=9$} & Type of asthma & Total & Failure & Mild attack & Moderate attack \\
\cline { 2 - 6 } & Mild (intermittent and mild persistent) & 20 & Nil & Nil $(\mathrm{n}=6)$ & Nil $(\mathrm{n}=14)$ \\
\cline { 2 - 7 } & Moderate (moderate persistent) & 29 & 5 & $3(\mathrm{n}=16)$ & $2(\mathrm{n}=13)$ \\
\cline { 2 - 6 } & Severe (severe pesrsistent)persistent & 14 & 4 & $2(\mathrm{n}=8)$ & 2 \\
\hline
\end{tabular}
\end{tabular}

Table 12: Failures in Non betamethasone group $(n=37)$

\begin{tabular}{|l|l|l|l|l|l|}
\hline & Type of asthma & Total & Failure & Mild attack & Moderate attack \\
\hline \multirow{2}{*}{$\begin{array}{l}\text { Total } \\
\text { failures }=17\end{array}$} & Mild (intermittent and mild persistent & 20 & 8 & $2(\mathrm{n}=14)$ & $6(\mathrm{n}=6)$ \\
\cline { 2 - 6 } & Moderate (moderate persistent) & 14 & 6 & $2(\mathrm{n}=9)$ & $4(\mathrm{n}=5)$ \\
\cline { 2 - 6 } & Severe (severe pesrsistent)persistent & 3 & 3 & $3(\mathrm{n}=3)$ & No cases \\
\hline
\end{tabular}

\section{Discussion}

The study was done to find out how, early administration of single dose betamethasone affects hospitalization rates in asthma. Asthma is a leading cause of chronic disease in childhood and is one of the most frequent admitting diagnosis in children's ward. The prevalence as well as severity is on the increase worldwide. ${ }^{[1]}$ Studies have been conducted to treat acute attacks of asthma at the earliest to reduce hospitalization rates. Tal $\mathrm{A}$ et al has reported that methylprednisolone given within $30 \mathrm{~min}$ of acute attack reduces hospitalization. ${ }^{[9]}$

In this study there were 100 patients. 74 responded and 26 did not. The lack of response included either failure during treatment or failure during follow up. The responders and non- responders were analyzed to know the factors responsible. The age and sex distribution between the two groups were identical (mean age $4.76 \mathrm{v} / \mathrm{s} 4.67$, sex male : female ratio $1.08 ; 1 \mathrm{v} / \mathrm{s} 1.17: 1)$. Majority (56.9\%) came from urban areas, but the distribution of patients between the two groups were comparable (55.4\% and $57.7 \%$ respectively).

History of pollution and passive smoking was present in 86 patients, but there was no statistical difference between the 2 groups.

A positive family history was also not significant in causing response because $71.6 \%$ of responders and $69.2 \%$ of nonresponders had positive family history. This was also identical.

The distribution of type of asthma also did not affect the response.

Inj betamethasone was given to 63 patients, of which 54 responded and it was not given to 37 patients, of which 20 responded. This difference as found to be statistically significant $(p<0.001)$. the reason for effectiveness of Inj betamethasone was probably due to the following factors- it was given as early as possible, within 17 hours in all patients. It is a long acting steroid. Its affinity for glucocorticoid receptors is very high.

Other factors studied were duration of attack and the type of asthma attack at presentation.

The duration of attack at presentation was found to be an important factor in determining response. The duration of attack was found to e significantly shorter among responders than non-responders (5.91 hours v/s 8.5 hours) (SE of 


\section{Jayasree; Single Dase Intramuscular Betamethazane}

difference 0.83 compared to observed difference 2.59 )

This alone was not important because among the nonbetamethasone group, out of 37 patients 20 responded and 17 failed. The duration of attack at presentation ranged from 1 to 12 hours with mean of 5.75 hours and SD 2.64 among responders and 3-12 hours with a mean of 7.35 hours and SD of 2.42 aong non responders. This difference in mean was not statistically significant (SE of difference 0.832 and observed difference 1.6).

Thus both, administration of betamethasone and duration of attack at presentation contributed to response. This is further suggested by the following finding.

Among 63 patients in the betamethasone group, 54 responded and 9 failed. The mean duration of attack among responders was 5.67 hours (range 1-17; SD 2.63)and among non-responders, it was 10.67 hours (range 5.12 hours and SD 3.86). this difference was statistically significant (SE 1.23 and observed difference 5).

The type of attack was also important in determining the response. Out of 100 patients in the study, 56 had mild attack and 44 had moderate attack (defined according to standard definition)

In patients with mild attack, 30 received betamethasone, of which 25 responded and 26 did not receive betamethasone of which 19 responded. Statistical analysis done using Fishers Exact test showed $\mathrm{p}=0.544$, ie the response produced by betamethasone was not statistically significant.

In patients with moderate attack, 33 received betamethasone, of which 29 responded and 11 did not receive betamethasone, of which 10 did not respond. Fishers Exact test showed that $\mathrm{p}$ value was 0.0004 . in other words, betamethasone contributed significantly to response in moderate attack of asthma.

\section{Limitations of the study}

- It was not blinded study

- There is a possibility of placebo effect. The patients in non-betamethasone group were not given any IM placebo injections to avoid this.

- Small sample size

\section{Conclusion}

- Administration of single dose of betamethasone is effective in reducing hospitalization rates in acute asthma

- Maximal effect is seen if the duration of attack at presentation was less than 6 hours.

- Betamethasone contributes to the effect significantly if patient has moderate attack at presentation

- In mild attack of bronchial asthma, Inj betamethasone did not contribute to response significantly.

\section{References}

1. Weitzman M. Gortmaker SL, Sobol A M et al. recent trends in prevalence and severity of asthma. JAMA 2668:2673,1992.

2. Weiss KB, Wagner DK. Changing patterns of asthma mortality; JAMA 264, 1683

3. Gergen PJ, Weiss KB (Centers of Disease Control)- changing patterns of asthma hospitalization among children 1979-1987. JAMA 1990264:1688-1692

4. RC Bone-year book of pulmonary diseases 1992-pp30-31

5. Rudolph's textbook of paediatrics. 19th edition. Appleton and Lange. 509

6. RC Bone-year book of pulmonary diseases. 1994.p 74

7. Clinical pharmacology 7th ed. By Lawrence DR and Benette. Churchill Livingstone. P552

8. Essentials of medical pharmacology 3rd ed by KD Tripathi. Jaypee Brothers.p 260

9. Tal A, Levy M, Bearman JE. Methylprednisolone therapy for acute asthma in infants and toddlers. Paediatics.86: 350,1990

10. Potter PC. Current guidelines for the management of asthma in young children. Allergy, asthma and immunology research 2(1): 1-13. 2010

11. Cutrera R, Baraldi $\mathrm{E}$ et al. management of acute respiratory diseases in pediatric population: the role of oral corticosteroids. Italian J Pediatrics 43 (1). 2017

Copyright: ( $)$ the author(s), 2019. It is an open-access article distributed under the terms of the Creative Commons Attribution License (CC BY 4.0), which permits authors to retain ownership of the copyright for their content, and allow anyone to download, reuse, reprint, modify, distribute and/or copy the content as long as the original authors and source are cited.

How to cite this article: Jayasree P. Role of Single Dose Intramuscular Betamethazone in Reducing Hospitalization Rates in Acute Asthma. Asian J. Clin.Pediatr.Neonatol.2019;7(1):35-39.

DOI: dx.doi.org/10.21276/ajcpn.2019.7.1.9

Source of Support: Nil, Conflict of Interest: None declared. 